\section{A Magyar Társadalomtudományi Egyesület megalakulása}

Előszó

z alábbi tanulmányban a magyar szociológia intézményesülésének egy ez idáig Akevéssé vizsgált és elemzett alakzatával kívánok foglalkozni: a Magyar Társadalomtudományi Egyesülettel, bemutatva a kialakulásához vezetố folyamatokat, az Egyesület megszületésének körülményeit és a formálódó eszmei koncepciókat. A hazai szociológiatörténet korábban sokat vizsgált jelensége, a Huszadik Század címủ folyóirat és a hozzá kapcsolódó Magyar Társadalomtudományi Társaság előtérbe helyezése érthetổ abból a szempontból, hogy a Társaság, amellett, hogy a magyar szociológia intézményesülésében úttörổ szerepet vállalt magára, a korszakban a leginkább újitó, radikális gondolatok megjelenítője is volt egyúttal; azonban ez nem feltétlenül indokolja az új tudománnyal, a szociológiával foglalkozó másik társaság, az Egyesület mellőzését, elképzeléseinek, eszméinek és egész mû́ködésének feldolgozatlanságát. A feldolgozatlanság véleményem szerint annak (is) köszönhetô, hogy a 60-as évek közepén-végén újjászerveződő magyar szociológia a fennálló államszocialista rendszer ideológiai pressziója miatt nem fordulhatott egy konzervatív, nemzeti szellemú szociológiai társaság munkássága felé. Az elemzés idóbeli kerete jelen tanulmányban az 1907-es évvel bezáruló események köre. A tanulmány megírásakor elsősorban két forrásra támaszkodtam. Egyrészt az Egyesület létrehozásának előkészítési és szervezési munkálatairól, illetve a formálódó elképzelésekről megjelentetett Egyesületi közleményekre, másrészt pedig a Magyar Társadalomtudományi Szemlében megjelent vonatkozó témájú munkákra.

\section{Előzmények}

\subsection{A Magyar Társadalomtudományi Társaság megalakulása}

hazai szociológia protoszociológiai korszakát követően, melyben bár jelentős álAlamtani, jogbölcseleti kérdéseket tárgyaltak a szerzők igazi módszertan felhasználása, és még a szociológia tárgyának körvonalazása nélkül, a XIX. század végére felhalmozódtak mindazon társadalmi kérdések és problémák, melyek lehetővé tették a szociológia tudományának hazai megszületését; mintegy szükségszerú következmény volt e társadalomtudomány életre kelése. A magyar szociológia kialakulásának intézményes kezdetei tehát XIX. század utolsó évtizedére tehetôek, hiszen ekkor- táit jött létre a budapesti egyetem jogi karán fiatal hallgatókból és jogászokból álló kis csoport (közéjük tartozott többek között Somló Bódog, Jászi Oszkár, Vámbéry Rusztem és Gratz Gusztáv) Pulszky Ágost és Pikler Gyula professzorok köré csoportosulva, akik a nyugat-európai szociológiai iskolák felé kitekintve kívánták múvelni a jogbölcseletet. Ez a kis közösség az új társadalomtani ismeretekkel felvértezve látott hozzá a magyar társadalom vizsgálatához, s az új tudomány, a szociológia népszerúsítéséhez. 1900 januárjában kiadták folyóiratuk, a Huszadik Század elsố számát, egy évvel késóbb pedig megalakult a Magyar Társadalomtudományi Társaság. A cél és a feladat adott volt: a régi (liberalizmus, konzervativizmus) és új eszmék (szocialista) mentén, tudományos módszerrel vizsgálni a magyar társadalmat, ezzel összefüggésben pedig a régi Magyarországból való kimenetként a társadalmi, politikai, gazdasági, kulturális-mûvelốdési átalakulás elősegítése. A folyóirat kezdeti sikerét leginkább annak köszönhette, hogy számos eszmei irányzat képviseltette magát lapjain, ekként nem tényszerủ az a megállapítás, hogy a folyóirat és a Társaság már ekkor a polgári radikális eszmék mentén szerveződött volna. A Társaság kezdetben a spenceri organikus szociológia alapjaira épüló társadalomtudományos szervezetként indult' s a kor európai szociológiájának törekvése, elérendó célja fogalmazódott meg Magyarországon is, azaz: ,....miként fejlődik ... terméketlen, primitív bölcselkedés olyan egzakt tudománnyá, amely nem csupán kifejezéseiben, terminológiájában, hanem egész rendszerében, elsôsorban pedig módszerében azzá lesz, amivé a szociológiának feltétlenül lennie kell: természettudománnyá."’ . A későbbiekben, Spencer halálát követốen a Társaság szakított a spenceri organicista társadalomképpel.

A Társaság látszat-egysége nem tartott sokáig, hiszen 1901. tavaszától a konzervatív tagság már nem kívánt aktívan részt venni a közös munkálatokban³ ${ }^{3}$ majd két évvel késóbb újabb törés következett be. Az egyik tábor (Jászi, Somló, Wildner) azt a véleményt osztotta, hogy a jövóben a Huszadik Századnak egyáltalában nem kellene napi politikával foglalkoznia, inkább csak szakmai, tudományos írásokat közölnie. A másik tábor - többek között Gratz vezetésével - ellenben azt képviselte, hogy a politikának feltétlenül meg kell jelennie a lap hasábjain, hiszen a Huszadik Század egyrészt ennek köszönhette gyorsan kivívott népszerûségét, másrészt pedig politikai küldetése az, hogy színtere legyen a progresszív, liberális gondolatoknak. A többség, vagyis Jásziék azonban úgy határoztak, hogy a politika nemkívánatos eleme a folyóiratnak, így ennek hatására Gratz lemondott a szerkesztói pozíciójáról't. Újabb távolodási momentumként lehet értékelni a radikálisabb és a konzervatívabb tagság között az 1904 tavaszán megrendezett konferenciát A társadalmi fejlődés iránya címmel, amelynek célját a Társaság akként határozta meg, hogy mindazon társadalmi eszméket, ,,melyek a nemzeti lét alakulására okvetlenül visszahatnak” egy-egy szakavatott ismeróje mutasson be, hogy ezáltal mindazon téveszméket szertefoszlassák, amelyek a tárgyalt gondolati rendszerekhez a közgondolkodásban kapcsolódtak; ezt követôen pedig vitákat szerveztek az elhangzottakkal kapcsolatban. Az elóadásokon elhangzottak, valamint a kapcsolódó hozzászólások olyan mélységủ eszmei távolságot mutattak az egyes elôadók között, mely véleményem szerint már ekkor teljes mér- 
tékben megkérdőjelezte a Társaság és a folyóirat egységességét, miként Jászi megfogalmazta Tíz év címú cikkében: „Az egység jóformán csak annyi volt, hogy mindenk elégedetlen volt az akkori közéletnek egyik vagy másik jelenségével, s elmaradtnak vagy korruptnak vélte az azt intézố emberek többségét."

\subsection{Belpolitikai válság Magyarországon 1905-1906 között}

z ellentétek kicsúcsosodásában döntő szerepet játszott az 1905-1906-os belpoliA kai válság, melyről éppen ezért feltétlenül szólnunk kell röviden.

Az 1905 januárjára kitűzött parlamenti választások eredményeként Magyarországon megtörtént az, amit korábban elképzelhetetlennek tartott az uralkodó és a közvélemény: 1867 óta először esett az meg, hogy a kormány és pártja, a Szabadelvú Párt elveszítette abszolút többségét az általános választásokon, s a legtöbb szavazat az ellenzéki Függetlenségi Pártra esett. Bár a kormánypárt elvesztette többségét, a hatvanhetes alapokon álló pártok (Andrássy vezette disszidensek, Bánffy Dezsô alapította új párt, a nemzeti párt és a függetlenek) továbbra is többségben voltak a Parlamentben. Tisza és pártja vereségét az okozta, hogy „képtelennek mutatkozott a Monarchia dualista áramlatain belül mutatkozó gazdasági és politikai érdekellentétek rugalmasabb eszközökkel, politikai módosításokkal történô átmeneti rendezésére.”7 A pártok és a közvélemény is egyaránt elfogadhatónak tartotta a koalíciós kormányzást, azonban Ferenc József a választások után Tiszát bízta meg a kormányzati ügyek ideiglenes továbbvitelével, bár ezzel párhuzamosan hozzákezdett az alkotmányos megoldás kidolgozásához. Az uralkodó, a megoldáskeresés eredményeként február 3-án felajánlotta Andrássy Gyulának a koalíciós kormány megalakítását, mely döntésével június közepéig elhúzódó kormányzati huzavona kezdôdött. A disszidensek vezetôje nem volt képes kihasználni az ölébe hullott lehetôséget, sem ekkor, sem két hónappal később, hiszen a függetlenségi párt követelése, az önálló vámterület létrehozása nem volt sem Andrássy, sem Ferenc József számára elfogadható, továbbá az uralkodó Andrássy katonai kívánalmai iránt sem mutatott engedékenységet. A hazai politika érdeklődése 1905 tavaszán már egyértelmủen a vámkérdés körül folyt, s a koalíció programját tartalmazó áprilisi feliratban szereplő, a távoli jövőre halasztott önálló vámterület megvalósításának ötletét a legtöbb hazai érdekcsoport támogatta. A májusban is folytatódó koalíciós tárgyalások zátonyra futottak, ezért Ferenc József, megkerülve a koalíciót, egy ügyvivố kormány kidolgozásának tervét vette fontolóra. Ennek eredményeként június 18-án felmente Tiszát, egyben kinevezte a királyi testôrség kapitányát, báró Fejérváry Gézát a kormány élére. A király Fejérváry számára kijelölte a követendő irányvonalat is, melyben lényegében az áprilisi felirat ${ }^{8}$ elképzeléseit fogalmazta meg, a katonai követelések egyértelmû elutasításával. Fejérváry alkotmányellenes kormányának megalakulása egy több mint egy éves válságperiódus kezdetét jelentette Magyarországon. Kristóffy József belügyminiszter a munkásság megnyerése érdekében tervbe vette a választójogi reform felújítását (ezzel egyben meghatározta a további politikai diskurzus témáját), azt remélve, hogy ezzel elkerülheti a további sztrájkok és tünteté- sek sorozatát. A szociáldemokraták a választójogi mozgalom élére álltak, ezzel szemben a koalíció tulajdonképpen elutasította a választójogi reformot, mely döntésük a munkásság körében heves felháborodást váltott ki, az ellenzéki politikusok - köztük Bartha Miklós, Kossuth Ferenc - pedig igyekeztek a munkásságot negatív színben feltüntetni, s az országot a szocializmus veszélyével riogatni. A választójogi küzdelemben fontos megemlíteni az 1905. augusztus 26-án a nyilvánosság előtt megjelenô Általános Titkos Választói Jog Ligát, melyet Jászi, Gratz és még négy társuk alapított. Céljuk az volt, hogy egyesítsék azon politikai erőket, melyek valamilyen módon támogatták és kiálltak a választójogi reform mellett. A koalíció felismerve, hogy elônyére válhat a késóbbiekben, ha meg tudná szerezni a liga vezetôi pozícióit, saját embereit próbálta a vezetőségbe ültetni, kevés sikerrel és hatékonysággal. A szeptember 15-re tervezett munkásmegmozduláson, a „Vörös pénteken” a fốvárosban korábban soha nem látott munkástömegek mentek ki az utcára tüntetni. A függetlenségi pártnak válaszolnia kellett az eseményekre: a pártértekezleten ismét felmerült a választójogi reform szükségessége, ám végül úgy határoztak, hogy a reformról csak a nemzeti követelések teljesülését követôen érdemes beszélni. Az uralkodó szeptember 23-ára rendelte magához a koalíció képviselőit, bízva abban, hogy az ellenzéki pártok engedve makacsságukból, elfogadják az általa felajánlott kormányprogramot, ám érdemi tárgyalás és döntés nem született a felek között, az ellenzék dolgavégezetlenül tért vissza Magyarországra. Szeptemberre és október elejére a szociáldemokraták és a koalíció között viszonyt leginkább az ellenségeskedés állapotával lehet leírni, jelentôs utcai összecsapások bontakoztak ki a felek között. Eközben a király szeptember végén elôvette a hónap elején lemondott Fejérváry bárót, hogy október 16-án ismételten kinevezze a kormány élére, aki programjában ígéretet tett a társadalmi-gazdasági problémák kezelésére, ám a program igazi jelentốs eleme az általános, titkos és községenkénti szavazati jog kidolgozásának deklarálása volt, ám „valójában nem teljesen általános és egyenlố szavazati jogról volt szó. A társadalmi és nemzeti cenzus megmaradt volna. Fejérváry elôadása szerint a szavazók számának megháromszorozódására lehetett számítani.”9 Ezzel párhuzamosan a koalíció a választójogi reform ismételt elôvétele miatt még hevesebben fordult szembe a Fejérváry kormánnyal.

1905 őszén megindult a koalíció átrendeződése, s a hatvanhetes eszmék mentén történổ összefogása. Az alkotmánypárt, az új, hatvanhetes eszmék alapján november 19-én alakult meg, vezetője Andrássy Gyula lett, s programjukból már kihagyták a katonai követeléseket. Novemberre a koalíció és a kormányzat között még élesebbé vált a viszony, növekedett az ellenzék által támogatott zavargások száma, s ebben az idốszakban lett a legerősebb a koalíció szocializmusellenessége, annak sajtó általi közvetítése, továbbra is szembehelyezkedve az általános választójogi reformmal. 1906 elejére az ellenzék bizonyos csoportjai - leginkább a hatvanhetes alapokon álló pártok - szóba hozták a kormányra kerülés érdekében Ferenc József követeléseinek elfogadását, ám végül e csoportok háttérbe szorultak. Január végén Andrássy ismét az uralkodóval tárgyalt a koalíció módosított programjáról, melyben megfogalmazódott az önálló vámterület távoli jövốre vonatkozó megvalósítása, illetve a katonai 
engedményeket a szavazópolgárok döntésétől tette függővé. Ferenc József február elején elutasította a követeléseket. Februárban a Parlament feloszlatásának eseménye borzolta a koalíció és a lakosság tömegeinek kedélyállapotát, s tüntetéseket helyeztek kilátásba, ám mindezek mellett az uralkodó és a koalíció szinte folyamatosan tárgyalt egymással, melynek áprilisra lett meg az eredménye. Április 8-án a kompromisszumok révén megalakulhatott a koalíciós kormány, melynek elnöke Wekerle Sándor lett, akit maga Kossuth Ferenc javasolt a pártszövetség részéról, s ugyanekkor lett felmentve a Fejérváry-kormány. Az új kormány programjában javarészt elfogadta Ferenc József programját, s a választójogi reform is helyet kapott, igaz, csak mint a legutolsók között megvalósítandó elemek egyike. Az eskütételt követôen a kormány kiírta az új választásokat, melyet április végén és május elején le is bonyolítottak.

\subsection{A Magyar Társadalomtudományi Társaság válsága}

z 1905-1906. évi belpolitikai válság eseményei és hatásai átgyưrúztek a TársadaAlomtudományi Társaság és a folyóirat múködésébe is. 1905 nyarán Gratz Gusztáv körlevelet írt a szerkesztốbizottság tagjaihoz, melyben az események kapcsán kifejtette azon véleményét, hogy sajnálatos módon a Társaság elkanyarodott eredeti célkitűzéseitől, s túlságosan a radikális és szocialista eszmék mentén szerveződtek a munkálatok, s ismét hitet tett a napi politika közvetítése mellett. A szerkesztóbizottság válaszlevelében Gratz vádjait visszautasította: „Mi csak a nagy elvekkel és az irányokkal foglalkozhatunk, de nem azzal, ami azokból a mai szomorú politikánkba belefér" ${ }^{10}$ Egy évvel késốbb következett be az igazi szakítás, melyre okot a fentebb tárgyalt Kristóffy-féle politikai manôver adott. A Társaság rendes évi választmányi választásán Kristóffy belügyminiszter társasági tagságát a szabályok szerint megújították, melynek eredményeként Gratz és Hegedús politikai támadást indított a belügyminiszter ellen, hiszen korábbi ígérete ellenére a választójogi ígéreteket nem hajtották végre, s ezért helyére másik személyt javasoltak a választmányba, azonban e kérésüket nem vették figyelembe. 1906. július 20-án lemondott a Társadalomtudományi Társaság elnöke, Andrássy Gyula, melynek következtében a közgyủlés öszszehívása szükséges lépéssé vált. Ekkor már tisztán látszódott a két tábor: a nemzeti érzelmû, liberális jobbszárny (Gratz, Hegedüs Loránt, Wolfner Pál) és a polgári radikálisok, szocialisták (Jászi, Somló, Pikler) csoportja. 1906. augusztus 7-én következett be az események utolsó mozzanata: a sebtében összehívott rendkívüli közgyưlésen a polgári radikális és szocialista csoport gyổzedelmeskedett, a Gratz-Hegedôs-Farkasféle csoportot pedig kiutasították a társaságból, melyet a szerkesztőség a következő kijelentésével kommentált: „,... Társadalomtudományi Társaságban egyszerúen ama differentáció folyamata ment végbe, mely a közel jövőben az egész országban le fog folyni. ${ }^{11}$ ”, $\mathrm{s}$ a „modern társadalmi haladás” fog gyôzedelmeskedni a „,megkövült hatalmi maradiság felett". Ezt követổen a Társaság és a Huszadik Század teljes egészében a polgári radikálisok és szocialisták szellemi irányítása alá került, az új programot, akárcsak az első szám megjelenésekor, most is Jászi közvetítette „Az új Magyarország felé"12 címủ tanulmányában.

\section{A Magyar Társadalomtudományi Egyesület megalakulása}

zt követốen tehát, hogy 1906 augusztusában a korábban a Társaságból kilépett Alkonzervatív erốk után a liberális jobboldali tagság is kivonult, a távozók hozzáláttak saját társadalomtudományi fórumuk megszervezéséhez. 1906 novemberében a létrehozandó Magyar Társadalomtudományi Egyesület elókészítô bizottsága felhívást tett közzé, mely szerint céljuk egy nemzeti alapon fennálló társadalomtudományi egyesület megalapítása, mivel szükségesnek tartják, ,hogy a társadalomtudományoknak magyar szellemú és történeti alapon álló, de a korral haladó és lehetôleg sokoldalú művelésére a magyar nemzeti továbbfejlődés szolgálatára megfelelő szervezet és életműszer létesüljön."13 Az Egyesület, melynek székhelyét a pezsgő közélettel rendelkezô székesfôvárosban kívánták berendezni, mihamarabbi feladatául egy saját folyóirat, a Magyar Társadalomtudományi Szemle kiadását tûzte ki, azonban csak 1908-tól teremtôdtek meg ehhez az anyagi kondíciók. A bizottság felhívásban már szerepel az Egyesület szakmai múködésének az alapítók által meghatározott kettôs kritériuma, egyben eszmeiségük credo-ja:

- a magyar nemzet aktuális, de a múltban gyökeredző társadalmi, gazdasági kérdéseivel kell foglalkozni,

- s mindezt szigorúan tudományos, objektív és összehasonlító alapon, pártpolitikai irányzatok befolyásától mentesen kell végezni.

1906. november 21-én az elsố felhívás aláírói jelenlétében az Országos Magyar Szövetség helyiségében Gaal Jenô elnöklete alatt megalakult az előkészítô bizottság, mely két albizottságot választott soraiból. Az elsố számú albizottság, melynek tagja dr. Gaal Jenô, dr. Apáthy István, dr. Timon Ákos, dr. Földes Béla, dr. Thirring Gusztáv, dr. Ajtay József és dr. Szemenyei Kornél, feladatául az Egyesület alapszabályzatának kidolgozását kapta. A második számú bizottság feladata a propaganda vezetése, az Egyesület népszerűsítése volt, dr. Marczali Henrik, dr. Gaal Jenő, dr. Hornyánszky Gyula, gróf Bánffy Miklós, dr. Vári Rezsố, dr. Farkas Pál, dr. Thirring Gusztáv és dr. Jancsó Benedek részvételével.

Az 1907. április 28-ára összehívott alakuló közgyűlésen elfogadták az Egyesület szervezeti alapszabályát, valamint megválasztották a választmány tagjait. 1907. június 3-án, vasárnap 11 órakor a mủegyetem tanácstermében került sor a választmány megalakulására, melyen megjelentek a választmányi tagok. Az alakuló ülés célja az igazgatóság és a tisztikar megválasztása (három titkár, pénztárnok, ellenôr, a szakbizottmányok megválasztása) volt; elsóként tehát a választmányi tagok egyhangú döntéssel megválasztották a három igazgatót: Apáthy Istvánt, Gaal Jenốt és Jancsó Benedeket, majd ezt követốen megalapították a hat szakbizottságot: jogi, közgazdasági, társadalomtudományi, szociálpolitikai, munkásügyi és a szabadoktatási bizottságokat. Ezután került sor a titkárok, a pénztáros és az ellenôr megválasztására. A választmány a továbbiakban döntött az egyesület saját szakfolyóiratának megalapításáról és 1908 januárjában történổ kiadásáról, valamint a választmány az alábbiakban állapodott meg: 
- Kassán és Kolozsvárott létrehozzák a helyi bizottságokat,

- az ügyviteli szabályok kidolgozása az igazgatóság feladata lesz,

- ez eleddig jelentkezettek automatikusan az Egyesület tagjává válnak,

- az igazgatóság feladata lesz a tagdíjak beszedése az alakulási költségek fedezésére. A következố választmányi gyủlésre 1907. október 10-én került sor, mely első feladatának azt tekintette, hogy az Egyesület saját szakfolyóirata a lehetô leghamarabb megjelenhessen, melynek pontos idốpontjául a következó év január 15-ét jelölték meg, a szerkesztôi pozíció betöltésére pedig dr. Palágyi Menyhértet kérték fel. A november 26-ai ülésen a választmány elhatározta, hogy több nyilvános elôadást fog rendezni az Egyesület, annak érdekében, hogy céljait és elképzeléseit a közvélemény, a közönség mihamarabb megismerhesse. Az előadások megtartására Apáthy Istvánt és Palágyi Menyhértet kérték fel.

\section{Az Egyesület koncepciói}

z Egyesület céljairól, illetve az elốtte álló feladatokról már közvetlenül az alaAkuló közgyưlésen értesülhetett a hallgatóság, illetve a tagság, hiszen Gaal Jenő megnyitóbeszédében és Apáthy István előadásában már pregnánsan megfogalmazódtak az alapelvek, s a késốbbi előadásaikban és tanulmányaikban ők, illetve Palágyi Menyhért is lerakták a további munkálatok elvi alapjait.

A szellemi vezetôség - Apáthy, Gaal és Palágyi - a célok és feladatok tekintetében nagyjából közös állásponton volt az Egyesület megalakulásakor. Gaal hangsúlyozza, hogy a feladat, amit az Egyesület magára vállalt, nem könnyú: „az egész magyar nemzet által maradandó haszonnal folyton szem elốtt tartandó társadalomtani igazságokat tisztázni"14, s ez utóbbiak alapján a magyar nemzet számára az igazán kedvező és hatékony irányt kell kimutatni és érvényre juttatni. Jelszava: a Magyar Társadalomtudományi Egyesület legyen tudományos és magyar! Mit is értett ezen a kívánalmán Gaal? Az Egyesület először is a tiszta tudományosság minden kritériumát betartva fogalmazza meg elképzeléseit, azaz legyen teljesen független, tárgyilagos, csak a tényeket vizsgálja a természeti törvények mindenkori szem elôtt tartásával. Másodszor pedig az Egyesület legyen magyar, azaz a hazai társadalmi viszonyokat, problémákat tekintse legfontosabb vizsgálati tárgyának, melynek során Gaal szerint „érvényesíteni kell az önzetlen magyar nemzeti érzést" ${ }^{15}$, valamint a hazai szociológusoknak nem elsősorban az emberiség, hanem a magyar nemzet, társadalom java érdekében kell munkálkodni és szolgálni. Tehát nem nemzetközi szociológiát kell múvelni, hanem magyar szociológiát: társadalmi tudományt csak nemzeti alapon lehet sikerrel művelni. Apáthy szintén a fentiek mellett tesz hitet: olyan társadalomtudományi egyesületet kell létrehozni, mely magyar társadalomtudományt mủvel. Nem magyar egyesületet a társadalomtudomány múvelésére, hanem egyesületet a magyar társadalomtudomány mûvelésére. A tudományt magyarul mûvelni, a szellemi eszközöket a magyar nemzeti sajátosságokból meríteni, s azt a nemzet továbbfejlôdésének szolgálatába állítani. Összességében tehát szigorúan tudományos megállapítások és diagnózisok szükségeltetnek a magyar nemzet zsákutcából történô kivezetéséhez és a megfelelően átgondolt és megtervezett kedvezố fejlôdési pályára állításához, miként Apáthy hangsúlyozta: „Nem elméleteket szőni csupán, hanem tenni, hatni is akarunk, és pedig a mai nemzedékre, nem egy jövendőre." ${ }^{16}$

Az Egyesület értékviszonyulását egyértelmûen jelzi, hogy a korszak forgalomban lévố társadalmi eszméi közül melyeket érezte magáénak. Mieloott azonban ennek tárgyalásához hozzákezdenénk, néhány fontos dolgot le kell szögezni. A XX. század eleji társadalmi eszmék - gondolok itt az anarchizmusra, konzervativizmusra, liberalizmusra és szocializmusra - tartalma, célkitűzései és eszközei egészen más jellegűek voltak, mint amit XX. század végén, XXI. század elején tapasztalhattunk. Ez természetes jelenség, hiszen e nagy társadalmi eszmék is állandó változáson mentek keresztül a XX. században, s igyekeztek alkalmazkodni az adott korszak megváltozott követelményeihez s problémáihoz. Az anarchista és szocialista törekvések korabeli megítélésére a XX. század elsố évtizedében rávetette árnyékát a nagy munkástüntetések és - sztrájkok sorozatai, az elsố orosz forradalomban tapasztalt negatívumok; az újkonzervativizmus megjelenésére a szocialista és liberális csoportok reagáltak hevesen, s a fejlődés akadályozóit látták képviselôiben; a liberalizmus ellen pedig mind a szocialisták, mind a konzervatívok felléptek, elóbbiek bírálva az elnyomó kapitalista politikaigazdasági-társadalmi rendszer kiépítéséért, utóbbiak értékromboló tetteiért.

Az Egyesület kapcsolódott a XIX. század harmadik harmadában megjelenố neokonzervatív áramlathoz, ekként egyfajta konzerváló álláspontra helyezkedett be, mely konzerváció elsôsorban a magyar társadalomban fennálló nemzeti értékekhez és intézményekhez kapcsolódóan kristályosodott ki, azonban e megôrzés nem mindenekfelett megkövetelt jellegű, hanem az ésszerűség által behatárolt. Miként ezt Gaal hangsúlyozta: az emberiség természetének „a haladás és a conservativismus észszerû váltakozása felel meg”17, ezért feltétlenül szükséges eltávolítani „intézményeink korhadt, elavult és magukat túlélt részeit, mivel a maradiság azzal az óriási veszéllyel fenyeget, hogy a múlt sok, még mindig becses alkotását a rohamos átalakulás elsepri." ${ }^{18} \mathrm{~A}$ konzerváció, miként az intézmények esetében is láthattuk, nem kizárólagos, így a tudomány esetében is a fentiek érvényesek: „Minden tudományos igazságnak el kell tưrnie, hogy bármely pillanatban kétségbe vonják és alapjait új vizsgálat alá vessék. Ha nem tûri, akkor már dogma és nem beszélünk róla többé."19 Mint a fentiekból kitűnik, a liberalizmus számukra nemkívánatos jelenség, mely értékromboló és kapkodó haladást próbál megvalósítani, s újításai mindig öncélúak. Gaal szerint a liberalizmus megjelenése biztos jele annak, amit ő a nemzeti életösztön hanyatlásával magyaráz. A nemzeti életösztön Gaal megfogalmazásában „abban áll, hogy a nép minél több egyéne külön-külön és szerves közösségeikben mélyebb gondolkodás és nagyobb nehézségek nélkül, mintegy tapintat által vezettetve, önkéntelenül és megszokásból túlnyomólag azt tegye, ami neki és a legnagyobb szerves közösségnek, melyhez tartozik, hosszabb időt és gyakorlatot tekintve mindig a leghasznosabb." ${ }^{20}$ Tehát egyfajta spontán racionalitás mentén cselekednek az egyének, 
úgy, hogy az mindig kedvezó a nemzet számára. Ha ez nem kellóképpen erôs a nemzetek életében, akkor jelenik meg a liberalizmus. Amiként a konzervativizmus és a liberalizmussal kapcsolatos állásfoglalás az Egyesület vezetôségének tanulmányaiból megállapíthatóan viszonylag egyértelműnek tủnik, a szocializmussal kapcsolatosan az egység kevésbé állapítható meg. Apáthy magát szocialistának tartja, ám elutasítja az egyoldalú gazdasági szocializmust (túlzottan egyoldalú magyarázatnak tartja), és az ezt létrehozó német és osztrák szocializmust, s egy, a sajátos magyar viszonyokon nyugvó szocializmus létrehozását sürgeti: „Tudományos alapon, egy magyar szocializmus kialakulását munkálni: ez a Magyar Társadalomtudományi Egyesületnek egyik fổ feladata." ${ }^{21}$ Palágyi Apáthyval szemben fogalmazta meg álláspontját, ő kifejezetten a szocializmussal szemben helyezkedett el. Elsổ lépésként, amikor a szociológia kialakulását vizsgálja, Saint-Simonhoz érve kijelenti, hogy ő is inkább az osztályok keletkezésével és uralmának kérdésével foglalkozott ahelyett, hogy a nemzetet vizsgálta volna, s ennek okaként az utópista szocialista sajátos élettörténetét jelöli meg. Palágyi tehát az osztályokat, mint sajátos vizsgálódási tárgyat eleve elveti és károsnak tekinti²2. Marxról szóló tanulmányában hasonlóképpen jár el: először felvázolja, hogy a marxi internacionalizmus - mely a valóságban nem is internacionális, hanem csupáncsak német, ekként a németség uralomra töréséért küzd - nem kedvez a nemzet fejlődésnek; majd pedig ezen megállapítását igyekszik igazolni Marx élettörténetének elemzésével. Palágyi meglátása szerint, ha megvizsgáljuk Marx elméleti munkásságát, akkor azt tapasztalhatjuk, hogy az attól függốen alakult és változott, hogy Marx éppen hol élt: a Rajna-vidék, Párizs és London más-más elméleti formációkat hozott be elméletébe, s az egyéni eseményeket - Palágyi szerint - túlzó és káros eljárásával általánosította a világtörténetre vonatkozóan.

Az Egyesület a szociológia tudományát kizárólag nemzeti alapon kívánta múvelni, s ekként nem a magyar társadalmat, hanem a magyar nemzetet tekintette a szociológiai vizsgálódás tárgyának. Palágyi a szociológia kialakulásának vizsgálatakor jutott arra a következtetésre, hogy a szociológia hibás alapokról indult ki, hiszen amellett, hogy a Saint-Simon által felvetett problémákkal (osztályok kialakulása és uralma) kezdett foglalkozni, nem távolította el magából a comte-i, spenceri naturalista szemléletet. ${ }^{23}$ Ez utóbbi, az organicista iskola - mely Palágyi szerint nem más, mint szimpla tévelygés, Spencer, De Greef, Lilienfeld és Schaeffle tévelygése - hozadéka az, hogy metaforái révén, mellyel a társadalmat vizsgálni igyekezett, a szociológiára kettôs veszély leselkedett: egyrészt a legjelentősebb szociológiai fogalom, a nemzet kikerü szemlélődésének centrumából, másrészt pedig ezzel párhuzamosan nem lesz képes arról nyilatkozni, hogy valójában mi vizsgálatának tárgya. Ennek oka nem más, min hogy az organicista szemlélet a nemzet fogalmát nem tudta megfeleltetni semmilyen, a természet világából vett analógiával, s így nem is vizsgálta. Palágyi kijelenti, hogy szerencsére az organicista iskola hanyatlásban van, s helyét egyre inkább a kritikai vizsgálódás veszi át. Nézete szerint minden társadalmi tudomány lényege a nemzetfogalom, s a szociológia létrejöttéhez csak ebbốl lehet kiindulni. Ez utóbbival Apáthy is egyetértett, azonban ô Palágyival szemben kifejezetten az organicista tanítás mel- lett foglalt állasst, mely bizonyos szempontból érthetó, hiszen Apáthy a Ferenc József Tudományegyetem Állattani Intézetének professzoraként folytatta kutatásait, ekképpen szemlélete több irányból alakult. Apáthy megfogalmazza azon vágyát, - mely egyébként a szociológia létrejöttének időszakában a társadalomtant művelők egyik legalapvetóbb kívánalma és célja volt - hogy a társadalomtan legyen természettudomány, mellyel összefüggésben a természettudományokat három csoportba sorolta be, - az anorganikus természettudományok,

- élettudományok,

- társadalomtudományok csoportjába.

Véleménye szerint a szociológia leginkább az élettudományokkal, s közülük is a fejlődéstannal van a legszorosabb kapcsolatban, s megfogalmazásában „Társadalomtannak (szociológiának) nevezhetjük ama törekvések foglalatát, melyek a társadalm együttélés és az emberi továbbfejlődés törvényeinek és föltételeinek megismerésére vonatkoznak és az együttélésnek és a továbbfejlődés föltételeinek az emberi boldogulást leginkább szolgáló szabályozását keresik." ${ }^{24}$, és a szociológia olyan fejlődéstan, amely a gyakorlati alkalmazásra kell, hogy törekedjen. Apáthy december 10-én megtartott elôadásában ezt tovább taglalja, hiszen itt már az élố szervezet (organizmus) és a társadalmi szervezet analógiáját hozza: miként az élổ szervezetnek alapegysége a sejt, a társadalmi szervezeté pedig a család, mely család révén integrálódik az egyén a társadalmi szervezetbe. Az egyes ember, az egyén a társadalmi szervezetnek nem a sejtje, hanem elemi orgánuma. Egy másik tanulmányában a szociológiát a tudomány két fổ csoportjának eredôjeként, a természettudományok és a társadalmi/történet tudományoknak mintegy közös metszéspontjaként definiálta, a társadalomtan négy alapigazságát pedig a következókben jelöli meg:

- van emberi fejlődés,

- az emberi fejlôdés következménye a társadalmi együttélés,

- az igazi fejlổdés a független továbbfejlổés,

- az emberi fejlôdés nemzetenként determinált. ${ }^{25}$

Nézôpontja szerint, bár a szociológiában és természettudományokban megfigyelt törvényszerűségek nem azonos jellegűek, a társadalomtanban is érvényesnek kell lennie a természettudományok négy sarktételének:

„1. Causa aequat effectum elve, azaz az ok és okozat viszonya: ok nélkül semmi sem történik.

2. Egy magában teljesen egynemủ rendszer önmagából kiindulólag nem változhatik úgy meg, hogy részei egymástól különbözőkké legyenek.

3. Változásra képes rendszerben a változás mindig onnét indul ki, ahol a változásra való hajlandóság, illetôleg a változásra törekvő erố a legnagyobb, föltéve, hogy ez azt az erốt semmi sem ellensúlyozza.

4. Minden, ami történik, csak úgy történhetik, amint megtörténik, vagyis az okoknak egy adott constellációja következhetik."26

Apáthy organicista, darwinista iskolára emlékeztetố elképzelései jó néhány kérdést felvetnek, melyek közül kettốt feltétlenül megemlíteni szándékozok: 
Egyrészt Apáthynak az élő szervezetekrôl és társadalmi szervezetekról szóló koncepciói véleményem szerint mindenképpen visszalépést jelentenek a korábbi - azaz a szakadást megelôzó - állapothoz képest, hiszen a Társadalomtudományi Társaság már jóval korábban, hozzávetôlegesen Spencer 1903-as halálát követôen eltávolodott az evolucionista, organicista szemlélettól, s egyre inkább a polgári radikális, szocialista alapokra helyezte tevékenységét.

Másrészt érezhetố - bár egymás számára nem kimondott - ellentét feszül Palágyi és Apáthy között az organicista-evolucionista álláspont tekintetében, azonban legalábbis az 1908-as évben ebből - jelenlegi ismereteim szerint - nem történt semmiféle öszszeütközés a két tudós között.

A haladás, fejlődés törvényeinek megállapítása a szociológia legelsố, önmaga által felállított feladatának bizonyult, elég csak Comte, Spencer, és Durkheim munkásságát áttekinteni e kijelentés megalapozására. A haladás és fejlődés a magyar történelemben olyan jellegű követelmények, melyek a reformkortól kezdve meghatározták a magyar társadalom minden szféráját, $\mathrm{s}$ attól függően, hogy milyen jellegú megoldások kristályosodtak ki, nagyjából két álláspont különböztethetố meg:

- egy nyugati, külföldi mintákat, modelleket meghonosítani kívánó álláspont, és

- egy autochton, a hazai eróforrásokra, értékekre és intézményekre építő elképzelés. A Társaság, főleg 1906-tól kezdődően egyre inkább hitet tett a radikális, gyors változások mellett, ám az Egyesület ezzel ellentétes felfogást tett magáévá. Elképzelésük szerint a társadalmi, nemzeti fejlôdés csak lassan, nyugodt tempóban hajtható végre, tehát egyfajta értékőrző, fontolva haladás lehet igazán hatékony. Apáthy a forradalmakat, mint tartós változásokat kieszközölő módszereket elveti, mivel szerinte a fejlődést siettetni és kierőszakolni felesleges és kártékony. Ezzel összefüggésben a szociológia és az értelmiség feladatául a sajátos nemzeti fejlôdési törvények múltbeli és jövốbeli tartalmának tudományos meghatározását tûzte ki az Egyesület, hiszen álláspontjuk szerint minden nemzet számára sajátos nemzeti fejlődéstörvények alapján lehet csak kidolgozni a szükséges feladatok körét. Az intézmények, megoldások átvételét Apáthy elveti, s álláspontja szerint csak olyan intézmények kellenek, ,,amelyek magyar talajból sarjadznak s a magyar nemzet történetébe visszanyúló gyökerekból táplálkoznak.”27 Palágyi szerint addig, míg a szociológia nem képes bebizonyítania, hogy a nemzetek létrejötte szükségszerû az emberiség történetében, addig az emberi haladás lehetetlenség. ${ }^{28}$

A nemzet mint fogalom és mint központi vizsgálódási tárgy kitűntetett szerepet játszik az Egyesület eszmei koncepciójában, ennélfogva viszonylag gyakran tárgyalt elem. Meggyôzốdésük szerint a nemzet mint formáció felette áll akár a társadalom, akár az állam formációin, ez a legnemesebb emberi szerveződés, ,,egyetemes jellegú, olyan közösség, mely a saját egyéni módja szerint az emberiség összes életfeladatainak megoldására vállalkozik." ${ }^{29}$ Fontos megemlíteni, illetve árnyalni a képet: a nemzet ilyetén jellegú hangsúlyozása, kiemelése nem vezet egy agresszív-nacionalista szemlélet vállalásához. Apáthy hangsúlyozza, hogy bár a fejlổés csak nemzeti kereteken belül, a nemzeti értékeken alapulva történhetik meg, fontosnak tartja a külvilág felé tekintést is, hiszen mint írja: mindenkitôl és mindenütt tanulni kell, csak arra kell figyelni, hogy ezt miként interpretáljuk, ültetjük a magyar társadalomba. ${ }^{30}$ Ezzel összhangban, Palágyi, amikor Kant és Fichte nyomán vizsgálja a nemzet és a világpolgárság lehetôségeit, amellett hogy az utóbbit elveti, feltétlen hitet tesz a nemzetek közötti kölcsönös együttmúködés és versengés mellett, mert meglátása szerint „aki saját nemzetének kiválóságát a többinek lebecsülésére alapítja, az nem juthat el a nemzet igazi fogalmához." ${ }^{31}$ Mivel az Egyesület a nemzeti eszme ilyetén jellegú hangsúlyozását tekintette fontos elvének, ezzel párhuzamosan viszont elutasította a túlzott internacionalista szemléletet, többek között ezért is határolódtak élesen el a Társadalomtudományi Társaság nemzetköziségétôl.

\section{Az Egyesület tagsága}

hhoz, hogy bármely társadalmi szervezet megalakulását kellő távlatokban elemezAhessük, mindenképpen szükséges az adott szervezet tagságát is közelebbről szemügyre venni, s különösen érdekes lehet ez egy szociológiával foglalkozó egyesület esetében. A Magyar Társadalomtudományi Egyesületnek múködése kezdetekor összesen 519 természetes és 20 kollektív tagja volt. Az ügyrendi szabályzat szerint bárki tagja lehet az Egyesületnek, aki legalább két tag támogatását bírja, s elfogadja a szervezeti szabályokat.

A természetes személyeket elsôként az iskolai végzettségük alapján elemeztem. Az 519 személybốl csupán 284 fốnél (ez a teljes tagság 55 százaléka) lehetett egyértelmủen megállapítani, hogy a felsôfokú végzettségét milyen tudományterületen belül szerezte, a fennmaradó 234 fố esetében tehát erre nem volt mód. Összesen nyolc dimenzióban - jogi, orvosi, mérnöki, bölcsész, természettudományi, közgazdász/gazdasági, képzőmúvészeti, múvészeti - történt a vizsgálat, melynek során a következố eredményeket kaptam (1. táblázat). Mint a táblázat adataiból látható, az egyesületi tagság kétharmada a jogi végzettséggel rendelkezők közül került ki, ami nem meglepô a magyar társadalom viszonyainak ismeretében, hiszen még a XX. század elején is, akárcsak az azt megelôzó évszázadokban, a jogi végzettség volt a leggyakoribb végzettség a férfiak esetében, $\mathrm{s}$ az összes többi iskolai végzettség elmaradt mögötte.

1. táblázat - Az Egyesület tagságának felsôfokú iskolai végzettsége és a foglalkozási kategóriák

\begin{tabular}{|l|l|l|l|l|}
\hline \multirow{2}{*}{ Iskolai végzettség } & Foglalkozási szféra & \multirow{2}{*}{ Összesen } \\
\cline { 2 - 5 } & Ismeretlen & Állami, egyházi & Magán & \\
\hline jogi & 1 & 107 & 80 & 188 \\
\hline bölcsész & 3 & 33 & 5 & 41 \\
\hline orvosi & 3 & 16 & 2 & 21 \\
\hline mérnök & 7 & 8 & 2 & 16 \\
\hline gazdasági & 2 & 5 & 1 & 8 \\
\hline természettudományi & 0 & 6 & 0 & 6 \\
\hline képzỏmúvészeti & 0 & 1 & 2 & 3 \\
\hline múvészi & 0 & 0 & 1 & 1 \\
\hline Összesen & $\mathbf{1 6}$ & $\mathbf{1 7 6}$ & $\mathbf{9 2}$ & $\mathbf{2 8 4}$ \\
\hline
\end{tabular}

Forrás: A Magyar Társadalomtudományi Egyesület tagjainak névjegyzéke ${ }^{32}$ 
Mindemellett általában az összes állami (állami, vármegyei és városi) hivatal betöltéséhez elengedhetetlen volt a jogi ismeret, s mivel a hivatali pozícióknak lényegesen magasabb presztízse volt, mint a magánpályáknak, ez utóbbit igazolja az az adatsor is, mely az általam kialakított három foglalkozási szférában mutatja meg az egyes iskolai végzettségek megoszlását (1. táblázat): az összes állami, egyházi foglalkozások körében a jogi végzettséggel rendelkezô egyesületi tagok aránya közel kétharmad. A jogi végzettség után a bölcsész, orvosi és mérnöki végzettség volt a leggyakoribb a tagság körében. Összességében tehát kijelenthetjük: az Egyesület, legalábbis a tagságra jellemző végzettségeket és a foglalkozási jelleget tekintve, valósághủen reprezentálja a magyar politikai-gazdasági-kulturális vezetôs s értelmiségi réteget. Következő lépésben a természetes személyek lakhely szerinti megoszlását vizsgáltam. Budapest székesfốváros vezetố szerepe ezen a téren megkérdôjelezhetetlen, a tagság több mint fele itt lakott ${ }^{33}$, a fennmaradó 45 százaléka pedig összesen 48 vármegyében, azokon belül 93 településen lakott a tagsági viszony keletkezésekor. A fôváros után két erdélyi vármegye, Kolozs és Maros-Torda vármegye adta a legtöbb tagot, majd Veszprém vármegye és az ország középsô területei, illetve Sopron és Abaúj-Torna vármegye következnek a sorban, a déli és délkeleti vármegyék pedig átlagosan öt fốt adtak a tagság közé. Szinte érintetlen területnek számít Horvát-Szlavónország, valamint az északi vármegyék egy része: itt vélhetően a propaganda albizottság nem tudott hatékony munkát kifejteni.

Felmerült, hogy célszerû lenne a természetes személyeket abból a nézőpontból megvizsgálni, hogy közöttük mekkora a zsidó származásúak aránya. A listán szereplő valamennyi személyt megvizsgálva az alábbiakat találtam:

- a családnevek alapján történő behatárolás nem feltétlenül hozott teljesen megbízható eredményt, hiszen a németes hangzású családnév nem bizonyítéka a zsidó származásnak, ezért

- teljes bizonyossággal csupán néhány személyrốl lehetett megállapítani izraelita származását, így a táblázat mindezek figyelembevételével lett összeállítva (2. táblázat).

2. táblázat - A Magyar Társadalomtudományi Egyesület tagságának származás szerinti megoszlása

\begin{tabular}{|l|l|l|}
\hline \multirow{2}{*}{ Tagság összesen } & Szám (fő) & Megoszlás (\%) \\
\cline { 2 - 3 } & 519 & 100,0 \\
\hline Zsidó származású tagok aránya & 17 & 3,3 \\
\hline Nem zsidó származású tagok aránya & 502 & 96,7 \\
\hline
\end{tabular}

Forrás: A Magyar Társadalomtudományi Egyesület tagjainak névjegyzéke ${ }^{34}$

A kapott adatokat célszerủ a Társadalomtudományi Társaság ez irányú adataihoz hasonlítani: Litván Györgyék számításai szerint a Társaság tagságának közel fele zsidó származású volt, ez az arány az Egyesület esetében a megalakuláskor nem érte el az 5 százalékot, ezért felmerült bennem a kérdés, hogy a szakítás bekövetkeztében lehetett-e szerepe ennek a dimenziónak? Véleményem szerint közvetlenül nem, tehát arról nem beszélhetünk hogy nyílt ellentét lett volna a nem zsidó és a zsidó származású tagság között, közvetve azonban igen: a zsidó származású, nagyrészt szabadfog- alkozásúak inkább fogékonyabbak lehettek az úri Magyarország meggyökeresedett politikai-gazdasági-társadalmi berendezkedése elleni küzdelemre, ekként inkább politikai-gaza a gi-társ alóban radikális csatlakoztak olyan társadalomreformer szercc változásokért harcoltak (lásd Galilei-kör), és megfordítva: kevéssé szimpatizálhattak egy konzervatív szociológiai társaság elképzeléseivel, céljaival.

A kollektív tagságot tekintve azt mondhatjuk, hogy a húsz elemből mindösszesen két tag a budapesti, s az összes többi a déli országrész vármegyéibỏl került ki, s jellemzótag könyvtárak és oktatási intézmények (illetve az oktatási intézmények tanári kara) csatlakoztak az Egyesülethez.

\section{A Szemle létrehozása}

z 1907. június 13-i választmányi ülésen fogalmazódott meg az a cél, hogy az AEgyesület saját szakmai folyóiratát, a Magyar Társadalomtudományi Szemlét minabb létrehozzák. Az elsổ kiadás megjelenésének az idôpontját végül az október 10-i választmányi gyũlésen határozták meg: 1908. január $15{ }^{35}$, a szerkesztôség pedig Kolozsvárott került berendezésre Palágyi Menyhért vezetésével. A Szemle elsố számának fedőlapján szerepel a folyóirat célkitúzése, mely szerint: „A Magyar elsó szamána Társadalomtudomanyi Szemle kozol onáló tanúlmányokat a társadakló közéleti és fóbb segédtudományainak köréból; ismerteti a társadalomtant érdeklơ kőzzétí és irodalmi jelenségeket; gyúiti, bírálatosan rendezi és további fölhasználásra elókészíti árársadalomtan tudományos anyagát. Közli végül a Magyar Társadalomtudományi a társadalontán fölölolvasásokat Egyesület nyilvanos ulésein es szakértekezletein tartott é átanok választmányi üléés vitatkozásokat, valamint az Egyesület hivatalos értesítését annak valasztmányi uteé-

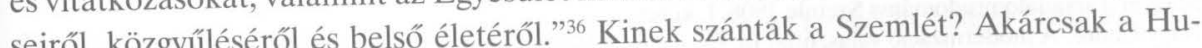
seirôl, közgyuleseró és bétsón ét is elsósorban az értelmiségnek készítették, hiszen szadíńsuk szerint ez a réteg az, mely hatékonyan képes közvetíteni a társadalom meglátásuk szerint ez a réteg az, mely hatekópzeléseit: „az értelmiség az apostol”.

Apáthy fogalmazta meg a Szemle elsố számában a várható rendezési elveket és a folyóirat egyes tematikus egységeit. ${ }^{37}$ Ezek szerint a megjelenő tanulmányok összesen négy tematikus egységbe oszthatók:

L Mindazon tudományok és az általuk megismert igazságok és ismeretek köre, me. Mindazociológia, mint születổ tudomány a megerôsödése érdekében felhasználhat, pl.: antropológia, régészet, társadalomtörténet, néprajz, lélektan.

I. Azon ismeretek csoportja, melyek a társadalmi fejlődés helyes eszközeit, módszereit tudományos igénnyel megállapítják, pl.: közegészségügy, nevelésügy, közgazdaság, politika, jogtudomány.

III. E tematikus egységbe a figyelemmel kísérendổ társadalmi jelenségek, nevezetesen: társadalmi mozgalmak általános aspektusa, illetve a gazdasági szocializmus tartoznak. IV A társadalomtudományi tevékenységek bemutatása: az Egyesület és más egyesületek munkásságának, múködésének bemutatása. 


\section{Végszó}

fenti tanulmányban kísérletet tettem a Magyar Társadalomtudományi EgyesüAlet kialakulásához vezetổ folyamatok fölvázolására, a formálódó koncepciók bemutatására. Természetesen, mint minden ilyen jellegû́ célkitűzés, nem valósulhatott meg olyanformán, hogy valamennyi fellelhető forrás felhasználásával tegyek eleget a célkitűzéseknek, ám igyekeztem a valóban releváns és fontosnak tartott tanulmányokat és egyéb írásos dokumentumot, illetve a bennük megfogalmazásra került tényeket felhasználni e dolgozat megírása során.

\section{Felhasznált irodalom}

Apáthy István: Haeckel és az Ember In. Magyar Társadalomtudományi Szemle 1908. I. kötet

Apáthy István: A Magyar Társadalomtudományi Egyesület legelsố teendổi In. Magyar Társadalomtudomány zzemle 1908. I. kötet

Apáthy István: A társadalomtan tudományos anyaga In. Magyar Társadalomtudományi Szemle 1908. I. kötet. Bolgár Elek: A szociológia fejlôdése és irodalma Magyarországon In. Litván György és Szücs László: A szociologia elsổ magyar mủhelye I. kötet Gondolat Kiadó, Budapest, 1973.

Dolmányos István: A koalíció az 1905-1906.évi kormányzati válság idején. Akadémiai Kiadó, Budapest 1976. Gaal Jenó: A Magyar Társadalomtudományi Szemle rendeltetése In. Magyar Társadalomtudományi Szemle .

Huszár Tibor: Nemzetlét - Nemzettudat - Értelmiség. Magvetố könyvkiadó, Budapest 1984.

Jászi Oszkár: Az új Magyarország felé In. Huszadik Század 1907. I. kötet.

aszi Oszkara: Tudomanyos publicisztika In. Huszadik Század 1900. I. kötet.

Kempelen Béla: Magyar Zsidó Családok. Makkabi Kiadói Kft. Budapest, 1999.

Különlenyomat a Huszadik Századból: A társadalmi fejlôdés iránya. Elổszó. Politzer Zsigmond és Fia könyvkeeskedése Budapest, 1904

Litván György és Szǘcs László: A szociológia elsổ magyar múhelye I. kötet Gondolat Kiadó, Budapest, 1973 Magyarorszag története 1890-1918. 1-2 kötet. Fốszerkesztố: Hanák Péter. Akadémiai Kiadó, Budapest, 1978. Magyar Társadalomtudományi Egyesület Közleményei II. Budapest 1907. Budapesti Hírlap Nyomdája. Függelék. A Magyar Társadalomtudományi Egyesület tagjainak névjegyzéke

Magyar Társadalomtudományi Szemle 1908. I. kötet

Nagy Endre: A modernizáció válaszútjai In. Eszme és valóság. Savaria University Press, Szombathely, 1993. Palágyi Menyhêrt: Marx és tanítása. Második kiadás. Szent István Társulat Kiadása, Budapest 1920.

Palágyi Menyhért: A nemzeti gondolat philosophiája In. Magyar Társadalomtudományi Szemle 1908. I. kötet Pók Attila: A magyarországi radikális demokrata ideológia kialakulása. Akadémiai Kiadó, Budapest, 1990

Társadalomtudományi Társaság válsága In. Huszadik Század 1906. XIV. kötet

Magyar Életrajzi Lexikon. Szerkesztố: Kenyeres Ágnes. Internetes formátum. Webcím: http://mek.oszk.hu/

es munkái. Internetes formátum. Webcím: http://mek.oszk.hu/03600/03630 Letöltve: 2006 november 13, 9:46:11

\section{Jegyzetek}

Jászi Oszkár: Tudományos publicisztika In. Huszadik Század 1900. I. kötet. 2. o.

Bolgár Elek: A szociológia fejlődése és irodalma Magyarországon In. Litván György és Szűcs Lászlơ: A szociológia elsổ magyar mủhelye I. kötet Gondolat Kiadó, Budapest, 1973. 81. o.

E döntésük összefügg a Pikler ellen indított támadásokkal, melynek során jogbölcseletét istenkáromlónak és hazaárulónak nevezték a konzervatív-egyházi csoportok.

4 Pók Attila szerint ez a döntés tulajdonképpen a polgári radikális eszmék melletti elkötelezettséget jelenti, hiszen így a korszak politikai berendezkedése ellen foglaltak állást: nem írnak a napi politikáról, így egybe elutasítják a politikai rendszert. Lásd: Pók Attila: A magyarországi radikális demokrata ideológia kialakulás. Akadémiai Kiadó, Budapest, 1990. 84. o. Különlenyomat a Huszadik Századból: A társadalmi fejlődés iránya. Elôszó. Politzer Zsigmond és Fia
könyvkereskedése Budapest, 1904.

6 Idézi Huszár Tỉbor: Nemzetlét - Nemzettudat - Értelmiség. Magvetô könyvkiadó, Budapest 1984. 152.o.
Dolmányos István: A koalíció az 1905-1906.évi kormányzati válság idején. Akadémiai Kiadó, Budapest 1976. 25.0.

8 Azaz a választójogi, adóügyi, közgazdasági és szociálpolitikai és katonai követelések, valamint az önálló vámterület kívánalma.

9 Dolmányos István: A koalíció az 1905-1906.évi kormányzati válság idején. Akadémiai Kiadó, Budapest 1976. 116.o.

10 Idézi Pók Attila: A magyarországi radikális demokrata ideológia kialakulása. Akadémiai Kiadó, Budapest, 1990. 155.o.

11 A Társadalomtudományi Társaság válsága In. Huszadik Század 1906. XIV. kötet 93.0.

12 Jászi Oszkár: Az új Magyarország felé In. Huszadik Század 1907. I. kötet. 1.o.

13 A Magyar Társadalomtudományi Egyesület alakulása In. A Magyar Társadalomtudományi Egyesület közleményei I. Budapest, Budapesti Hírlap Nyomdája, 1907. 4.o.

14 Gaal Jenố: A Magyar Társadalomtudományi Szemle rendeltetése In. Magyar Társadalomtudományi Szemle 1908. I. kötet 1. o.

15 Magyar Társadalomtudományi Egyesület alakulása In. A Magyar Társadalomtudományi Egyesület közleményei I. Budapest, Budapesti Hírlap Nyomdája, 1907. 9.o.

16 Apáthy István: A Magyar Társadalomtudományi Egyesület legelsổ teendôi In. Magyar Társadalomtudományi Szemle 1908. I. kötet 11.o.

17 Gaal Jenố: A Magyar Társadalomtudományi Szemle rendeltetése In. Magyar Társadalomtudományi Szemle 1908. I. kötet 4. o.

18 Gaal Jenô: A Magyar Társadalomtudományi Szemle rendeltetése In. Magyar Társadalomtudományi Szemle 1908. I. kötet 4.o.

19 Apáthy István: Haeckel és az Ember In. Magyar Társadalomtudományi Szemle 1908. I. kötet 84-85.o.

20 Gaal Jenố: A Magyar Társadalomtudományi Szemle rendeltetése In. Magyar Társadalomtudományi Szemle 1908. I. kötet 4. o.

21 Apáthy István: A Magyar Társadalomtudományi Egyesület legelsổ teendối In. Magyar Társadalomtudományi Szemle 1908. I. kötet 21. o.

22 Lásd bốvebben Palágyi Menyhért: A nemzeti gondolat philosophiája In. Magyar Társadalomtudományi Szemle 1908. I. kötet 24-25. o.

23 Palágyi megfogalmazásában a naturalizmus az a szellemi irányzat, mely rajong ugyan a természettudományokért, ám nem hatol annak mélyére.

24 A Magyar Társadalomtudományi Egyesület alakulása In. A Magyar Társadalomtudományi Egyesület közleményei I. Budapest, Budapesti Hírlap Nyomdája, 1907. 19-20.o.

25 Apáthy István: A társadalomtan tudományos anyaga In. Magyar Társadalomtudományi Szemle 1908. I kötet 65-66.o.

26 Apáthy István: A társadalomtan tudományos anyaga In. Magyar Társadalomtudományi Szemle 1908. I. kötet 69-70.o.

27 Apáthy István: A Magyar Társadalomtudományi Egyesület legelsố teendổi In. Magyar Társadalomtudományi Szemle 1908. I. kötet 16.o.

28 Palágyi Menyhért: A nemzeti gondolat philosophiája In. Magyar Társadalomtudományi Szemle 1908. I kötet 35.o.

29 Palágyi Menyhért: A nemzeti gondolat philosophiája In. Magyar Társadalomtudományi Szemle 1908. I. kötet 35.o.

30 Apáthy István: A Magyar Társadalomtudományi Egyesület legelsổ teendổi In. Magyar Társadalomtudományi Szemle 1908. I. kötet 16.o.

31 Palágyi Menyhért: A nemzeti gondolat philosophiája In. Magyar Társadalomtudományi Szemle 1908. I. kötet 38.o.

32 A Magyar Társadalomtudományi Egyesület Közleményei II. Budapest 1907. Budapesti Hírlap Nyomdája. Függelék.

33 Budapesthez számítottam többek között Újpestet is.

34 A Magyar Társadalomtudományi Egyesület Közleményei II. Budapest 1907. Budapesti Hírlap Nyomdája. Függelék.

35 Az Egyesület tagjainak évi tíz korona, külsổ elốfizetốknek évi húsz korona az elốfizetés díja.

36 Magyar Társadalomtudományi Szemle 1908. I. kötet. Fedőborító

37 Apáthy István: A társadalomtan tudományos anyaga In. Magyar Társadalomtudományi Szemle 1908. I kötet. 76-82.0. 